\title{
D’Artagnan még kitart. Az információs társadalomról, húsz év után
}

A lap egykori alapító főszerkesztője azt vizsgálja, hová jutott az információs társadalom narratíva az indulás (2001) óta eltelt húsz év alatt. Úgy véli, hogy azokra az alapkérdésekre, amelyeket egykor az információs társadalom elméleti irodalma tett fel, ma a társadalmi makroevolúcióval és a civilizációs kihívásokkal foglalkozó elemzések válaszolnak. A jövőt fürkészve pedig nem a posztinformációs társadalom körvonalainak keresése zajlik, hanem a posztbürokratikus kontrollstruktúra lehetségességéé. Az információ-és tudásgazdaság mellé felzárkózik a humángazdaság, az információtechnológia és a humán technológia, az új kulcsszavak pedig a digitális transzformáció köré rendeződnek, élükön a mesterséges intelligenciával és az adatkultúrával. A japán Society 5.0 koncepciót, amely a technológiai apparátust eszköznek tekinti ahhoz, hogy elvezessen egy haladottabb, humánusabb, emberléptékübb társadalmi állapot megteremtéséhez, a pragmatista Ipar 4.0.-ával veti össze. Befejezésül az információs társadalom elméletének közelmúltban elhunyt három testőrére (Tadao Umesao, Daniel Bell és Alvin Toffler) emlékezve gondolataik érvényességét és tartósságát fürkészi, hogy befejezésként Andrew Targowski egyre terebélyesebb életművére hívja fel a figyelmet.

Kulcsszavak: információs társadalom, társadalmi makroevolúció, bürokratikus kontroll, digitális transzformáció, humán gazdaság, humán technológia

\section{Szerzői információ}

Z. Karvalics László, vezető kutató, IASK/FTI, Kőszeg, egyetemi docens, SZTE BTK, https://orcid.org/0000-0002-3502-434X

Így hivatkozzon erre a cikkre:

Z. Karvalics László. „D’Artagnan még kitart. Az információs társadalomról, húsz év után”. Információs Társadalom XXI, 1. szám (2021): 48-72.

$=\quad$ https://dx.doi.org/10.22503/inftars.XXI.2021.1.2 $\rightleftharpoons$

A folyóiratban közölt müvek

a Creative Commons Nevezd meg! - Ne add el! - Így add tovább! 4.0

Nemzetközi Licenc feltételeinek megfelelóen használhatók. 


\section{D'Artagnan still holds on. On the Information Society, twenty years after}

The one-time founding editor-in-chief is tracking the way of information society narrative in the last twenty years since the setout of the journal. He argues that the fundamental questions, posited once by the theoretical literature of information society are answered today by analyses, dealing with social macroevolution issues and civilization challenges. And what we should try to find is not the silhouettes of the post-information society, but the feasibility of post-bureaucratic control structure. Human economy is catching up to information and knowledge economy, as human technology to information and knowledge technology. The new keywords of the discourse are well-set around the digital transformation, artificial intelligence, and data culture. The author confronts the pragmatist Industry 4.0. paradigm with the Society 5.0. plan of Japan, which aims at a more human-centered society, supported by all the capabilities of our technology. Finally, he recollects the three musketeers of information society thinking, recently departed (Tadao Umesao, Daniel Bell, Alvin Toffler), nosing after the validity and durability of their thoughts. In conclusion, he is drawing attention to the thriving, mature oeuvre of Andrew Targowski.

Keywords: information society, social macroevolution, bureaucratic control, digital transformation, human economy, human technology 
Alexandre Dumas ügyesen lovagolta meg három testőrének hatalmas népszerüségét, és olvasóinak legnagyobb örömére a bombasiker után egy évvel, már 1845-ben előállt a folytatással. Mindenki meglepetésére azonban nagyot szaltózott előre az időben, és úgy mesélte tovább a történetet, hogy majd egy emberöltőnyit ugrott át hősei életében. Ezért adta a regénynek a (magyarul, Jékely Zoltán fordításában) Húsz év múlva címet, és lett elég e két évtized is ahhoz, hogy az egykor elválaszthatatlan cimborák szanaszét széledjenek. Egyedül D’Artagnan maradt királyi testőr. Athos a tudománynak és a tudás átadásának él, Porthos hatalmas birtokán gazdálkodik és vigad, Aramis pedig egyházi öltözetben keres politikai kapcsolatokat.

A szomorkás-borongós hangulat szinte együtt jár azzal, ha egykori kedvencekre sok idő után pillantunk rá újra. És így vagyunk a tudományos diskurzusokkal is, amelyek ugyanúgy alakulnak át és öregszenek meg, mint a filmvászonra is többször átköltöző vidám kardforgatók.

\title{
„A közép a biztos út”. Az információstársadalom-kutatások három föiránya
}

\author{
„Melyik az, mely célra jut? \\ Itt egymásba összefutnak, \\ Egy csekély ponton nyugosznak ... \\ Vagy tán vége sincs az útnak”
}

Vörösmarty 1830-ban írott Csongor és Tündéjének hőse előtt „varázskörként” áll a „hármas útvég”, mögötte a végtelennel, s a Kalmár, a Tudós és a Fejedelem testesít meg egy-egy személyes kibontakozási-kiteljesedési lehetőséget. Ami Csongornak a boldogság, a társadalomkutatónak az az igazság (az érvényes állítások) keresése, amellyel képes újat mondani, vagy viszonyt kialakítani az újhoz (egyes alrendszerek vagy a társadalomegész friss fejleményeihez). Ezért nem mindegy, kit milyen kívánság és reménység int, von, ösztönöz valamelyik irányba indulni. Hiába ér össze ugyanis ezer szállal az információs társadalom három, végtelenbe nyúló problémauniverzuma: kérdésfeltevéseik, tudományterületi hátterük és absztrakciós szintjük annyira különbözik egymástól, hogy - mint az egykori testőröknek és a három allegorikus Vörösmarty-figurának - saját kérdésfeltevéseik, történeteik, azoknak pedig saját tanulságaik vannak. Kézenfekvőnek tűnik, hogy az „információstársadalom-tanulmányok” (infor-

\footnotetext{
${ }^{1}$ A kézirat lezárása közben érkezett a hír, hogy a Covid erősebbnek bizonyult kedves barátomnál. A nagyszerü újkor-történész és afrikanista a tudományos ismeretterjesztés rendszerváltás utáni megújításának egyik csendes hőse is volt, a társadalomkritikai gondolkodás magasszínvonalú képviselője, szerkesztő és tudományszervező.
} 
mation society studies) témakör alá sorolt három nagy, jól elkülöníthető témavilágot is egyesével vegyük szemügyre. Hol tartunk húsz év után?

\section{Athos és a Tudós: civilizációelmélet és történetfilozófia}

Kimondhatjuk talán, hogy az információs társadalom „nagy narratívája” körülbelül félszáz évet élt. A múlt század hatvanas éveinek sokat citált gondolkodói, az „alapító atyák”, Tadao Umesao, Jean Gottmann, Alvin Toffler, Daniel Bell, majd Yoneji Masuda és mások arra a kérdésre kerestek választ, hogy mi a szemünk láttára végbemenő mikroszintű fejlemények világtörténeti kontextusa. Milyen strukturális/paradigmatikus társadalomszerkezeti váltásról üzen a termelés, a foglalkoztatás, a munkavégzés, a fogyasztás és a végzettségi-müveltségi mutatók gyors átalakulása (amelyet nem a „leváltás”, hanem a „dominanciaátrendeződés” fejez ki talán a legpontosabban).

Ebben a fogalmi szerkezetben már elvétve akad teoretikus elvégezni való. A nagy váltás konstatáltatott, leíratott, analizáltatott. Talán még az is kijelenthető, hogy az új társadalmi állapot posztindusztriálisként megragadott természetét nem is volt szerencsés „információsnak” elnevezni egykor, mert az „információs” jelző később számtalan félreértés és mihaszna polémia forrásává vált. (Annak a mérhetetlen leegyszerűsítésnek köszönhetően, amellyel sok szerző a félig önkényesen választott elnevezésből kauzalitást kotyvasztott: a termelt és kezelt információmennyiség növekedésében és az információs ökoszisztéma átalakulásában találva meg, tévesen, a változások okát és magyarázatát. És ugyanerre vezethető vissza a 'tudástársadalom' fogalmának felívelő népszerűsége: ha egyszer az információs társadalom egyre kevésbé fejezi ki jól a társadalmi változások irányát, nosza cseréljük az információs jelzőt tudásra, hiszen „a tudás több, mint az információ”.) $)^{2}$ A Hankiss Elemér által kedvvel vetítgetett kép, amelyben egy szivárványszínű halacska az egyik gömbölyű víztartályból átugrik a másikba, félúton még tűnhet egy pillanatra szabadságnak (esetünkben: fogalmi innovációnak), csak ahol landolunk, az ugyanolyan, mint ahonnan indultunk (esetünkben: ugyanazért használhatatlan). Akár az információ, akár a tudás megváltozó szerepéről és helyiértékéről persze érvényes tanulmányok és könyvek sorát lehet írni, de fontosságukból

\footnotetext{
${ }^{2}$ Különösen a nemzetközi szervezetek világában vált igazi „buzzworddé” a tudástársadalom, hiszen esetükben a fogalmi újítások mindig önlegitimációs célokat is szolgálnak. AZ UNESCO például még az érintett szervezeti egységét is átnevezte információs társadalmiról tudástársadalmira (Knowledge Societies Division), és dokumentumaiban már csak az utóbbit használja. Eközben az élére állt a hajdan számos szakmai és tudományos szervezettel közösen tető alá hozott, két grandiózus világtalálkozóval (Genf 2003; Tunisz 2005) indult WSIS (World Summit on the Information Society) „folyamatnak”, amely azonban láthatóan megrekedt: immár 16 éve nincs folytatás, hiába a szűkkörű és magas szintű (High-level) fórumok, ismétlődő díjak és leltárszerű eseményjelentések (stocktaking reports). Ezek gyüjtőoldalát lásd https://www. itu.int/net/wsis/
} 
nem következik, hogy szükségszerủen társadalomleíró kategorizáció alapjául kell szolgálniuk. ${ }^{3}$

Ma úgy látom, az első szöget az információs társadalom fogalmának koporsójába épp az a James Beniger verte be, akinek a monográfiája, $A z$ irányítás forradalma az információs társadalomhoz vezető gazdasági, politikai és társadalmi folyamatok gyökereit volt hivatott megragadni. ${ }^{4}$ Eszerint a társadalmat összeabroncsoló, egyensúlyban tartó és a változásokhoz való alkalmazkodást biztosító kontrollstruktúrák 19. század közepi válságát az információtechnológiai innovációk révén lehetségessé váló kontrollstruktúra-váltás, a bürokratikus kontrollforradalom ütötte helyre - egyúttal megszülve azokat a dinamikákat, amelyek aztán majd száz év múlva az információs társadalom kialakulásához vezettek.

Az érdekes az, hogy Beniger adós maradt a kontrollstruktúra-fogalom köré épített teljes világtörténeti rekonstrukcióval, és nem adott választ arra a kérdésre sem, hogy mi idézte elő a kontrollválságot. Az utóbbi 5-6 évben, történészként, már én is ezekre a kérdésekre kerestem a választ, és arra jutottam, hogy a világtörténelmi folyamat az információs társadalom irodalmában megszokott toffleri „hullámok” (természeti-földműves-ipari-információs társadalmak) helyett valóban jobban megragadható az izonomikus, hierokratikus, arisztokratikus és bürokratikus kontrollstruktúrák egymást váltó paradigmáival. ${ }^{5}$

A mindenkori kontrollválságok okát pedig egy visszatérő feszültségforrásban véltem megtalálni. Amikor a változó környezeti hatásokhoz való csoportszintű alkalmazkodás során a reziliencia, az ellenálló- és öngyógyí-

\footnotetext{
${ }^{3}$ Ugyanezt gondolom egyébként az Ulrich Beck (1944 - 2015) által népszerűvé tett „kockázattársadalom” fogalmáról is. Beck (1986) látleletének nincs egyetlen olyan mozzanata sem, ami ne volna elmondható úgy, hogy nem alkot hozzá magas absztrakciós szintű társadalomtipológiát, hanem egyszerűen csak megállapítja, hogy a kortárs társadalom sok-sok attribútuma közül a kockázattal kapcsolatosakat látja felértékelődőnek. De az információ, a tudás, a hálózat, a kockázat legalább kezdeményező lépés, hogy a változások alapvető okai közül egyet találjunk és emeljünk ki kardinális jelzőnek. Nem szerencsések, sok félreértésre adnak okot, de legalább progresszív, bár sikertelen fogalmi törekvésnek tekinthetőek. Azokat a kísérleteket azonban, amelyek - egyetlen irányba kifacsarva a nagyon is pontos becki „mellékhatást” (Márkus 2003) -, valamely „árnyoldalban” látják a társadalom meghatározó vonatkozását, és legyártják a „dezinformációs társadalom” (disinformation society) vagy a „megfigyelés társadalma" (surveillance society) szószerkezeteket, már egyenesen a tudományos imposztorság kategóriájába sorolom. (Szerzőket pedig nem rendelek hozzá, hogy ne népszerűsítsem őket: bárki fellelheti a megfelelő keresőszavak beírásával a diskurzusvezéreknek a megfelelő kontextusképzést harsánysággal és riogatással ellensúlyozni igyekvő könyveit és írásait.) De mindennél bosszantóbb, amikor ezeket a neologizmusokat egy tanulmány preambulumában ráadásul felsorolásként adja meg valaki, hogy a „riválisok” közül a maga választása mellett érvelhessen - elfeledkezve arról, hogy ezek nem azonos mélységű, felbontású és funkciójú tipológiák részei. Egymás mellé sodrásuk egyetlen előnye, hogy ilyenkor különösen jól látszik valamennyi kísérlet közös módszertani hiányossága.

${ }^{4}$ Beniger könyvéről kiváló, részletes elemzést közölt a folyóirat hasábjain Füzesi és Holczer (2006).

${ }^{5}$ Minderről részletesebben lásd egy kéziratos mű leközölt fejezetében (Z. Karvalics 2019).
} 
tó képesség már nem elégséges, a megoldást az összekapcsolt közösségek méretének, mennyiségének és komplexitásának a növekedése kínálja, az erőforrás-felhasználás és a térbeli diverzitás révén megnyíló új szelekciós mechanizmusokra visszavezethetően. Csakhogy ez a túlélésvezérelt átalakulás a munkamegosztás átrétegződését és a hagyományos kontrollstruktúrák cseréjét is igényli, és szembekerül az egyensúlyteremtés korábbi hatalmi, intézményi és kulturális mechanizmusaival. Ahol az integráció és irányítás magasabb, újra működőképes szintje megteremthető, ott kontrollforradalom megy végbe, ahol nem, ott már nem is a szétesés-hanyatlás- vagy pusztulásforgatókönyvek lefutása a kérdés, hanem pusztán az időtartamuk. Az „összeomlás-forgatókönyvek” - amelyről oly szívesen írnak nagy monográfiákat lefelé ívelő pályára kerülő sztárszerzők - nem kivételes események, amelyeket körmönfont levezetésekkel kell megmagyarázni, hanem tipikus és jellemző lefutások. A kontrollforradalmak és a hozzájuk tartozó rendszerszintugrások a kivételesek és ritkák.

A 19. század kontrollválságát a nyersanyag-felhasználás, a kereskedelem, a termelés és a fogyasztás lokális rendszereinek planetáris méretűvé növekedése eredményezte. A rendszertermészetét tekintve a városhálózati társadalmakat felváltó birodalmi, politikai-diplomáciai karakterét tekintve nagyhatalmi szereplők arisztokratikus kontrollstruktúrái alkalmatlannak bizonyultak az anyag-, ember- és tudásáramlás felgyorsult folyamatainak koordinálására, és hathatós információkezelési megoldásokkal, részleges elitcserével és a folyamatok szabályozásának új módozataival bürokratikus kontrollforradalomba szaladtak. Ezzel egy jó évszázadra (nagyjából az információs társadalom hatvanas évekbeli megszületéséig) sikerült stabilizálni a konokul a még nagyobb összekapcsoltság felé tántorgó világot.

Csakhogy a bürokratikus kontrollstruktúra elemei közül a piaci koordináció, a nemzetközi politikai rendszer, a válságból válságba sodródó parlamentarizmusok és a modernitásnak a mindennapi élet kereteit megszabó intézményrendszere (az oktatástól az egészségügyig) láthatóan egyre kevésbé tud megfelelni azoknak a rendszerdinamikai kihívásoknak, amelyek a bolygóméretű integráció további előrehaladásából és az egyének és közösségeik megváltozó kontrollkörnyezet-igényéből következnek. Így a bürokratikus kontrollstruktúra keretein belül mind reménytelenebbnek tűnik a megküzdés a korábbi stabilizációs periódus által termelt krízisformákkal is. Elég, ha csak az alábbiakra utalunk: a klímaegyensúly megingása, a vízkörforgás megváltozása, a természetes élőhelyek pusztulása és az ezzel összefüggő járványfenyegetettség-növekedés, a társadalmi egyenlőtlenségek és a rendszerkockázatok növekedése. (Érdemes újra és újra fellapozni és problémalistaként olvasni az ENSZ Fenntartható Fejlődési Célok (Sustainable Development Goals, SDG) 169 részcélt tartalmazó dokumentumcsomagját.)

A társadalomelméleti horizontot pásztázva abban nincs vita, hogy korunkat az átmenetiség kategóriáiban lehet és kell megragadni és leírni. Ám hogy milyen tényezők hatására mi megy át mibe, és az átmenet finomszerkezetét 
milyen erők határozzák meg, ehhez keressük a legszilárdabbnak, időtállóbbnak és rugalmasabbnak tűnő elméleti-fogalmi keretrendszert. S azokra az alapkérdésekre, amelyeket egykor az információs társadalom elméleti irodalma tett fel, ma a társadalmi makroevolúcióval és a civilizációs kihívásokkal foglalkozó elemzések válaszolnak, amelyek immár olyan kategóriákhoz igazítják az alacsonyabb rendszerszintek tárgyalását is, mint a világrendszer, világtársadalom, világközösség vagy a globális koordináció. A jövőt fürkészve pedig nem a posztinformációs társadalom körvonalainak keresése zajlik, hanem a posztbürokratikus kontrollstruktúra lehetségességéé. ${ }^{6}$ Ezt azoknak az átmeneti formáknak az élő gyakorlatai teszik elképzelhetővé (és ezáltal rögtön normatívvá is), amelyek már megkezdték lebontani a bürokratikus kontroll klasszikus intézményi és irányítási modelljeit, életképes alternatívák esélyeit kínálva. S minél több ilyet találunk, annál inkább láthatóvá válik a régi, hierarchikus irányítási és egyensúlyteremtési mechanizmusok számtalan anomáliája, meg az intézményi és újraelosztási filozófiák, döntési és működési elvek és gyakorlatok elavulása, elalkalmatlanodása. ${ }^{7}$ A mindennapokat átszövő technológiai mező szinte minden feszültsége valójában innen eredeztethető. Ez ad hátteret a kortárs információs társadalmak lényeginek vélt jelenségeit feltáró anatómiáknak - a második út keresésének.

\section{Porthos és a Kalmár: szociológia, technológiafilozófia, társadalompolitika}

Kezdjük egy extrém friss példával.

A 2021. évi online digitális napon (március 19.) az uniós tagállamokat képviselő 27 miniszter által aláírt három nyilatkozat közül az első arról szól, hogy miként erősítse meg Európa saját digitális évtizede (Digital Decade) részeként a globális (pontosabban: Európa és annak afrikai, ázsiai, európai szomszédsági és latin-amerikai partnerei közti) konnektivitási hálózatokat, úgynevezett

\footnotetext{
${ }^{6}$ Ez az a pont, ahol a posztmarxista kritikai alapállás „összeér” az információs társadalom jövőképével. Talán a leginkább karakteres és letisztult megfogalmazásokkal Mészáros István (1930-2017), A tőkén túl írója él, amikor a lényegi egyenlőség követelményét körüljárva valójában a posztbürokratikus kontrollról beszél. „Az elkerülhetetlen történelmi kihívást az jelenti, hogy a társadalmi anyagcserét gyökeresen, minden szintjén át kell alakítani nem-hierarchikus módon működővé” (Mészáros 2015, 7). „Újraszervezni a társadalmat a döntéshozási hatalom átadásával a szabadon társult termelőknek: ez az egyedül járható útja-módja az értelmes tervezés bevezetésének ...Ebben az értelemben a globálisan életképes tervezés csakis egy laterálisan koordinált (vagyis tényleg nem hierarchikus) társadalmi újratermelési folyamat alapján képzelhető el” (Mészáros 2015, 7).

${ }^{7}$ Ez azonban véleményem szerint nem jelent „civilizációs összeomlást”, ahogy Polányit parafrazálva Marosán (2021) állítja: az átmenet sok-sok forgatókönyve közül ez kétségkívül egy, de csak számtalan együtt ható és előrejelezhetetlen esemény különös előfordulása esetén nő meg a valószínűsége. Marosán gondolatgazdag írását érdemes elolvasni, mert ő is a méretviszonyokkal megragadott makroevolúciós mozgásból (a globális ökoszisztéma 1989-re datált kiformálódásából) vezeti le a közelgő „nagy átalakulást”.
} 
adatátjárókon (Data Gateways) keresztül. ${ }^{8}$ A célkitűzés technológiai tartalma a nagyobb és biztonságosabb adatcserét lehetővé tévő földfelszíni és tenger alatti kábelek, műholdak és hálózati kapcsolatok fejlesztése, üzleti tartalma az európai szereplők által megcélozható adatközponttá válás forgatókönyve, amely az átjárók globális, biztonságos és agilis természetéből fakadhat. Lényegét tekintve azonban a 19. század utolsó harmadában a tenger alatti kábelekkel, távíróvonalakkal, majd telefonvonalakkal meginduló globális kommunikációs infrastruktúra kiépülésének felgyorsitásaként és elmélyítéseként is tekinthetünk rá, amely az adatvagyon cseréje és felhalmozása révén közelebb visz egy működőképes, de már csakis szupranacionális szinten elképzelhető és megvalósuló koordináció újabb szintjéhez.

Vajon eszünkbe jut párhuzamot vonni a legendás Bangemann-jelentéssel? Az európai iparági vezetők által dominált munkacsoport 1994-ben nyilvánosságra hozott stratégiai dokumentuma mindmáig az Uniós információstársadalom-politika alapvetésének számít. S noha minden alrendszerről tettek állításokat, az „információs társadalmi” karakter lényegében távközlés-liberalizációs és tarifapolitikai célokat szolgált. Nagyon is hatékonyan: negyed század alatt olyan infrastruktúra épült, amely ma elérhető áron ${ }^{9}$ szolgálja ki az igényeket a videokonferenciáktól az okostelefonos applikációkig. Izgalmas belegondolni, hogy a mostani adatátjáróktól húsz év múlva hová is vezethet el majd az út.

A Bangemann-jelentés után néhány évvel kezdtünk egykor - Manuel Castells és sok-sok követője meg epigonja nyomán - hálózati társadalomról beszélni, ha a kortárs társadalmi szcéna legfontosabb sajátosságát akartuk kiemelni. Ez a fogalmi fegyver a szociológia szinte valamennyi szokásos leíró kategóriájára alkalmazható volt, az identitástól a munka világáig. Ma már sokkal inkább az összekapcsoltság (a konnektivitás) különleges mértékét és az összekapcsolódó ágensek sokféleségét kifejező hiperkonnektivitást meg szuperkonnektivitást (Chayko 2017) hangsúlyozzuk, miközben az „emberek Internetjétől (Human Internet)” az „ipari Interneten (Industrial Internet)” és a „dolgok Internetjén (Internet of Things, IoT) ${ }^{10}$ ” át a „minden dolgok Internetjébe (Internet of Everything, IoE) szaladunk. A kilencvenes éveket uraló World Wide Web atyja, Tim Berners Lee ma az összekapcsolt adatok (Linked Data) világát népszerüsíti. A társadalom állandó jelzője az Uniós szótárban már nem az 'információs', hanem a 'digitálisan átalakult' (digitally transformed), az ENSZ

\footnotetext{
${ }^{8}$ https://digital-strategy.ec.europa.eu/en/news/digital-day-2021-europe-reinforce-internet-connectivity-global-partners

${ }^{9}$ S mintegy mellesleg: nem lehet a távhívások csökkenő díjai és az Internetes platformokon gyakorlatilag ingyenessé vált videobeszélgetések világa (a távolság összezsugorodása és legyőzése) mögött ismét csak a rendszerméret-növekedés jeleit látni.

${ }_{10}$ Önálló szakfolyóiratai: a nyílt hozzáférésű, 2020-ban indult negyedéves Internet of Things https://www.mdpi.com/journal/IoT (MDPI) és a 2014 óta jelenlévő, komoly statisztikai mutatószámokat felhalmozó IEEE Internet of Things Journal https://ieee-iotj.org/
} 
szótárában pedig a digitális transzformáció: a 2006-ban az ügynökségei közti koordinációra életre hívott UNGIS (United Nations Group on the Information Society) nevéhez a közelmúltban egyszerűen hozzábiggyesztették, hogy „for Digital Transformation”. ${ }^{11}$

A kulcskérdéseket már nem a hozzáférés és az információs kultúra és műveltség megteremtése, hanem az elképesztően differenciálódó problématér (digitális ökoszisztéma) társadalmi-politikai konnotációinak megértése és alakítása körül kell keresnünk. De hogyan? Lássunk ismét egy példát. Az EU közös kutatócentrumának élcsapata (Joint Research Centre, Centre for Advanced Studies, JRC CAS) 2018 és 2020 között hároméves kutatási programot indított, a szellemes DigiTranScope fantázianév alatt, amely a „digitális transzformáció és az emberi társadalom kormányzása” tárgyban ígért szintetikus kutatási eredményt. ${ }^{12}$ Egy ilyen cím láttán valami nagyon magas absztrakciós szintű, információstársadalom-kategóriákkal tusakodó zárótanulmányt várnánk - amit kapunk (Craglia 2021), az viszont valójában az adatkormányzás (data governance) tárgykörét körüljáró kompozíció, ahol az egyetlen vizsgált társadalomtechnikai változó az adatok megosztása és ellenőrzése. Láthatóan nem a társadalmon, hanem a digitális transzformáció természetén van a hangsúly. A szerzők nem a társadalmat vizsgálják, hanem olyan, néhány éve még nem is létező diskurzusokat, mint az adatmegosztás-készletek (data sharing pools), az adatszövetkezetek (data co-operatives), a bizalmi közadat-vagyonkezelők (public data trusts) és a személyes adatszuverentitás (personal data sovereignty), majd nem mulasztják el egy önálló fejezetben feldolgozni, miként segítheti a digitális játékkörnyezet a fiatal generációk megújuló energiatudatosságának fejlesztését. ${ }^{13}$

Mintha egyszerre látnánk a problémauniverzum ősrobbanását és egyidejű fraktálosodását.

Az ősrobbanás során egyre több kutatási tárgykör és publikációs objektum születik, egy szédületes tempóban táguló tématérben, s minden új elem azonnal tovább osztódik és differenciálódik, diskurzusgalaxissá nő, amelynek az új elemei is ugyanígy kezdenek viselkedni. Emiatt a részekben és a nagyobb egészekben is ugyanazokat a kérdéseket és szerkezeteket látjuk viszont, a távolodás ellenére, akármilyen perifériás szegletét is látogatjuk ennek a szakirodalmi kozmosznak, amelynek tudós démiurgoszai végső soron a társadalmi lét és a technológiai környezet komplexebbé válását igyekeznek visszatükrözni. ${ }^{14}$

Vegyük ezt szemügyre a blokklánc-technológia (blockchain) kapcsán. Az Információs Társadalomnak már 8 évfolyama jelent meg, amikor 2008-ban a

\footnotetext{
${ }^{11}$ https://www.itu.int/net4/wsis/ungis/

12 https://ec.europa.eu/jrc/communities/en/community/digitranscope

13 A jelentésről, részletesebben, magyarul: https://hirlevel.egov.hu/2021/03/22/a-digitalisan-atalakult-tarsadalom-iranyitasa-az-europai-bizottsag-kozos-kutatokozpontjanak-jrc-jelentese/

${ }^{14}$ Ezt a szükségszerű tematikai elaprózódást és tárgykör-kiszélesedést jól dokumentálja a folyóirat tartalomelemzése, ebben a lapszámban (Katona et al., 2021).
} 
Satoshi Nakamoto álnevet viselő diskurzusteremtő közzétette a blokklánc (megosztott főkönyvként működő decentralizált azonosítási, hitelesítési és titkosítási eljárás) gyakorlati megvalósítását felvázoló úttörő közleményét, amellyel megoldhatóvá tette egy valódi kriptovaluta (nem jegybank, hanem a hálózati közösség által létrehozott tranzakcióképes pénzforma) még 1998-ban felvetett lehetségességének kérdését is. S noha az első (bitcoin) tranzakció már 2009-ben létrejött, s az Internet egy-egy zugában megindult a tényleges kriptovaluta-bányászat (a pénzforma szoftveres megalkotása), a technológia csak 2015 körül lépett a világtörténelem színpadára, rögtön a reflektorfénybe, ahol sok-sok alrendszer tudatosította a maga számára a pénzforgalmon túli felhasználási lehetőségeket is. A sajtó után a tudományos közlemények világa is elkezdte témaként „felkapni” a blokklánc kérdéskörét. Több száz független közlemény tárgyalta már a legkülönfélébb szakmai folyóiratokban, amikor az Információs Társadalomban 2017-ben megjelent erről az első tanulmány. Ez a téma rövid történeti beágyazásán és ismertetésén túl társadalmi makroevolúciós kontextusba helyezte a blokklánc kérdéskörét, egy alternatív (nemcsak posztbürokratikus, hanem egyenesen poszthierarchikus) kontrollstruktúra egyik fontos összetevőjének lehetőségét üdvözölve benne (Nagy és Z. Karvalics 2017). A legelső, teljes egészében a blokklánccal kapcsolatos kérdéseknek szentelt tudományos szakfolyóirat 2018-ban indult, s ebben a pillanatban már öt szakosított orgánum foglalkozik a hatalmasra növekedett témauniverzummal. ${ }^{15}$

Ám akárhová irányítjuk a távcsövünket, mindenütt azt tapasztaljuk, hogy a technológiafejlesztés mérnöki és üzleti diskurzusai egyre kevésbé tudnak saját zárt, fekete lyukaikba fagyni. Irányt és tétet minden egyes technológia esetében a társadalmi valóság és a civilizációs kihívások kölcsönöznek, a felhasználhatóság és az alkalmazhatóság dimenziói mentén. De mindez fordítva is igaz: a hétköznapi lét megélése és szervezése, a társadalom irányítása és intézményeinek újratermelése elképzelhetetlen annak a technológiai apparátusnak a felfedezése, beemelése, „belakása” nélkül, ami szakadatlanul felkínálja magát használatra (és természetesen vásárlásra). Igazán izgalmas ráérezni, hogy a mindent átjáró technológia miként válik alkalmassá az elavuló kontrollstruktúra életciklusának meghosszabbítására, de eközben hogyan rendezi át mégis a különböző kontrollszíntereket, hogy egyre több helyen tegye lehetővé alternatív kontrollhatások kialakulását és megerősödését.

Elég, ha csak arra az aprócska személyi készülékre gondolunk, amelyet okostelefon néven ismerünk. Húsz évvel ezelőtt még a 'mobil mivolta' vonta magához a kutatói érdeklődést, annak a szabadságnak a megfizethető mámorában, ami a vezetékes megoldások világához képest egyfajta telekommunikációs reneszánszt ígért. Aztán 2007-től, az iPhone megérkezésével, majd a kifejezetten

\footnotetext{
15 The Journal of British Blockchain Association (JBBA) 2018, International Journal of Blockchain and Cryptocurrencies (IJBC) (2019) Frontiers in Blockchain (2020) Blockchain: Research and Applications (2020) Journal of Blockchain Research (JBR) (2021).
} 
okoskészülékekre szabott Android 2008-as debütálásával ${ }^{16}$ megkezdődött a valódi forradalom: a tömegesen elérhetővé váló masinák a hívások lebonyolításán túl már nemcsak teljes értékű személyi információkezelő instrumentummá lettek, hanem tartalomfogyasztási és közzétételi platformmá is. Orvosi diagnosztikai eszközzé, instant laboratóriummá, amellyel mérésműveletek végezhetőek. Pénztárcává és ügyintéző alkalmazássá. Az új eszköz újfajta polgárok kezében lapul: a 2011-es „arab tavasz” még a mobilkészülék ébredő hatalmáról üzent, az okostelefonok ma - más okoseszközökkel együtt - az autonómia, az áttekintő- és tranzakcióképesség új kontrolltereit nyitogatják, és innen is szétpermetezik az 'okos'- (smart) megoldásokkal kapcsolatos reményeket más irányokba.

Az okostelepülések (smart city, smart village) és az okoskormányzás (smart governance) követelése és gyakorlata a politikai szféra felé terelik az átalakuló kontrolligényeket. Immár nemcsak a folyamatok követése, leírása és megértése, hanem alakítása és irányítása is tét és cél. A normativitás (,milyen legyen?”) beköltözik a tudományművelés műhelyeibe és közleményfolyamába is, felváltva a historiográfiai és elméleti-fogalmi fókuszt.

Önszerveződő közösségek lépnek frigyre az aktivista tudománnyal - csendben és békésen, például állampolgári tudomány (Citizen Science) projektek révén, vagy hangosan és türelmetlenül, ha a klíma és a természet védelméről meg az emberközpontú oktatásról van szó, netán információs jogokért kell harcolni a képviseleti demokrácia kiüresedő mechanizmusai által döntési pozícióba emelt politikai elitcsoportok megfigyelési vagy titkosítási mesterkedéseivel szemben. És máris az információs társadalom harmadik narratívájánál járunk.

\section{Aramis és a Fejedelem: politika, stratégia, szabályozás}

Az információstársadalom-diskurzus első harminc évének (1961-1991) lovagjai elsősorban még olykor egymástól is elzárt társadalomtudományi porondokon léptek fel. Szociológusokat, építészeket, urbanistákat, filozófusokat és közgazdászokat sodort egymás mellé a posztindusztriális korszak szelleme, akik legtöbb esetben párhuzamos narratívákkal kezdték felépíteni az információs társadalmi szöveghagyományt. ${ }^{17}$

\footnotetext{
${ }^{16}$ Az okostelefon technikatörténete természetesen korábbi évekkel indítandó: 1992-ben az IBM Simon nevű érintőképernyős készüléke már valódi személyi asszisztensként (PDA, Personal Digital Assistant) igyekezett debütálni (https://www.szeretlekmagyarorszag.hu/multunk/ elso-okostelefon-a-vilagon-apple-samsung-ibm-nokia/). További részletekért lásd: https://netidok.reblog.hu/az-elso-okostelefon

${ }^{17}$ Sokan még mai napig nincsenek a kánonban, elég, ha Jean Gottmannra vagy Jean-Jacques Servan-Schreiberre utalunk), mások (mint Fritz Machlup) pedig tévesen soroltattak be az információs társadalom alapirodalmai közé. Nem véletlenül szenteltem egykor önálló tanulmányt mindhárom szerzőnek a folyóirat hasábjain (Z. Karvalics 2007; Z. Karvalics 2009a; Z. Karvalics 2009b).
} 
1991-től a stafétát ideiglenesen a politikai-stratégiai tervezés vette át: az úttörő Szingapúr jövő- és versenyképességet az információs társadalom fejlesztésétől remélő „intelligens sziget” vízióját vagy félszáz hasonló dokumentum követte alig tizenöt év alatt: vezető ország nem maradhatott nagy léptékü információs stratégia nélkül, de épp a „felzárkózók” és a „kicsik” (legyen az Malajzia, Észtország vagy Málta) számára ígért különleges lehetőséget az információs kultúra gyors adaptálása. S miközben egy élhetőbb, magasabb rendű társadalom víziójával kiáltottak Jézust ezek a kövérre hízott stratégiai dokumentumok, azért persze a gyors beavatkozások révén kiépíthető versenyképességi pozíciók (infokommunikációs niche-piacok) megszerzésének üzenetével Barabásnak értette mindenki, akinek volt füle a hallásra.

Ma már keresve sem találunk efféle „információstársadalom”-stratégiákat. ${ }^{18}$ A nagyhatalmi erőcentrumok, az Európai Unió és a világszervezetek a fraktálosodott versenytérben keresik a maguk távlati pozícióinak a megalapozását jelentő, időelőnyteremtő legjobb lépéseket (egy 'nagy' helyett sok 'kicsi'). A tervezési dokumentumok kulcsszavai ma a mesterséges intelligencia, az adatkultúra és 'okos'-entitások (köztük az okosvárosok és az okoskormányzás) rendszerinnovációi köré rendeződnek, s gyűjtőnévként terjed a 'digitális ökoszisztéma’.

Egyedül az információs társadalom tervezés D’Artagnanja, Japán képviseli az átfogó, bátran holisztikusnak vagy egyetemlegesnek nevezhető megközelítést, amely a technológiai apparátust eszköznek tekinti ahhoz, hogy elvezessen egy haladottabb, humánusabb, emberléptékűbb társadalmi állapot megteremtéséhez. Ez természetesen nem megy az ország megőrzött interoperabilitása és csúcsiparágainak versenyképessége nélkül, de a súlypontok egyértelműen arra esnek, hogy miként lehet az egyéneknek magasabb életminőséget biztosítani a tudatos tervezés révén átalakított struktúrák, intézmények és gyakorlatok révén.

\footnotetext{
${ }^{18}$ Ha sírfeliratot kellene illeszteni a különböző szakanyagokban jól feldolgozott hazai stratégiai kezdeményezések fejfájára, akkor az alábbi nekifutásokat kell felidézni. Az 1995-ös NIS-t (Nemzeti Informatikai Stratégia, a 2001-es NITS-et (Nemzeti Információs Társadalom Stratégia), majd azt követő Széchenyi Terv Információs Társadalom- és Gazdaságfejlesztési Programját, a 2003-as MITS-et (Magyar Információs Társadalom Stratégia) és késői utódjukat, a Nemzeti Infokommunikációs Stratégiát (2014 és 2020 között), amely végül is a mostani, patchworkszerűen építkező Digitális Jólét Programot alapozta meg. Közös jellemzőjük (beleértve még a két elemző-felkészülő kormányzati háttértanulmányt, az egyaránt 2000-ben született Tézisek az információs társadalomról és a Magyar válasz az információs társadalom kihívásaira című dokumentumokat is), hogy valójában nem a stratégiai előnyteremtés szándéka, hanem egy megalapozott változásérzékelésre épülő, követést és alkalmazkodást megcélzó fejlesztési keretrendszerek voltak. A kormányzaton belüli divizionális logika miatt valójában részben technológiai (infokommunikációs, informatikai, hírközlési), részben gazdasági súlyponttal, szinte érzéketlenül az információ- és tudásáram intézményi világának és nagy alrendszereinek (oktatás, kutatás, innováció) együttes kezelésére. Nem véletlenül lettek ezek a területek sok politikai cikluson keresztül a költségvetési harcok vesztesei (az egészségüggyel együtt).
} 
A szigetországban szinte hajszálpontosan félszáz éve fogtak hozzá mindehhez, az információs társadalom nemzeti célnak tekintett 1972-es tervével ${ }^{19}$, amely az ezredfordulóig határozott meg célokat, és 1985-re szerette volna megteremteni a kívánt információs társadalmi állapotot, amely a szabadidő növekedésével, a létfenntartási kényszerek alóli kiszabadulással, sikeresebb és elégedettséget eredményező önkiteljesítéssel, az értéktermelés és értékfogyasztás mélységben és időben való kiterjesztésével, részvételi demokráciával és önkéntesközösségekkel ragadható meg.

Ugorjuk át a köztes időszakot, amikor a tervracionális állami fejlesztés mintaországának minden ötéves terve az aktuális technológiai kihívás szempontjából gondolta újra az alapcélokat (nem elhallgatva, hogy azokból elég keveset sikerült a gyakorlatba átültetni) vegyük szemügyre a legutolsó stratégiai dokumentumot, a 2016-os Society 5.0. című szakanyagot. ${ }^{20}$ Ebben már nagyobb hangsúly esik ugyan a gazdasági fejlődésre, de minden gazdasági részcélt kizárólag a 'társadalmi problémák megoldása' körébe sorolt részcélokkal összekapcsolva tárgyalnak. És ezek a részcélpárok a magas életszínvonal, komfortérzet és életerő társadalmát hivatottak megteremteni: a Society 5.0. programszerüen a már 30-35 éve elért információs társadalminak mondott állapot meghaladása: humán társadalom (human society), amely egyúttal minden korábbinál okosabb (supersmart).

Bátran állítsuk szembe a Társadalom 5.0. elképzést a németországi fogantatású, de az egész euroatlanti világban hatalmas népszerüségre szert tett Ipar 4.0. koncepcióval, amely orkánként söpörte ki az információs társadalomnak még a szóhangulatát is a diskurzusokból, a társadalom helyére az ipart állítva.

A Társadalom 5.0 „emberközpontú, a gazdasági fejlődés és a társadalmi problémák megoldása közt egyensúlyt teremtő társadalom, amely magas szinten integrálja a kiberteret (cyberspace) és a fizikai teret (physical space)."11

Az Ipar 4.0. sok-sok meghatározása közül válasszuk ezt: „intelligens gyárakban ... kiber-fizikai termelési rendszerek segítségével, új, a korábbiaknál kedvezőbb fizikai jellemvonásokkal rendelkező anyagokból és új technológiák felhasználásával ... állítanak elő termékeket” (Monostori 2015; idézi: Szalavetz 2016,4).

Nagyon leegyszerűsítve: a Társadalom 5.0. könnyűszerrel magába olvaszthatja az Ipar 4.0. paradigmát, ám ez fordítva egyáltalán nem igaz.

\footnotetext{
${ }^{19}$ The Plan for Information Society - A national goal toward the year 2000" (Japan Computer Usage Development Institute), 1972. A terv részleteit a világ a projekt gondozójának, Yoneji Masudának a könyvéből ismerte meg (Masuda 1980).

${ }^{20}$ Részletesebb tájékozódáshoz remek kiindulópont a gazdagon illusztrált angol nyelvű Webes összefoglaló: https://www8.cao.go.jp/cstp/english/society5_0/index.html. A Society 5.0 koncepció Japán 5. Tudományos és Technológia Alaptervének (5th Science and Technology Basic Plan) volt része. Nagyívü elemzését lásd Holroyd (2020).

${ }^{21}$ „A human-centered society that balances economic advancement with the resolution of social problems by a system that highly integrates cyberspace and physical space.” Az idézet forrása az előző lábjegyzetben megadott összefoglaló (Ford.: Z.K.L.) .
} 
Természetesen kézenfekvő az ipari technológia változásának társadalmi hatáskövetkezményeit fürkészni (a magyar szakirodalomban is találunk ehhez fontos hozzájárulásokat ${ }^{22}$ ), de ez nem azonos azzal, hogy a tervezés és stratégiaalkotás kiindulópontja, alapvető igazodási keretrendszere a társadalom és az ember: ezt a szakadékot pedig csak jelképesen hidalja át a tudományos diskurzusokból a politikai közbeszédbe átszűrődő „digitális humanizmus” eszménye és programja. ${ }^{23}$

A digitális humanizmus maga nem több egy fontos, időszerü, érzékenységről és értéktudatról tanúskodó, részben morális kategóriákkal operáló kiállásnál egy szellemi pozíció, egy megközelítésmód mellett. Jó, hogy gesztusok tétetnek, de ez önmagában nem elég ahhoz, hogy a kortárs társadalomelméleti diskurzusok új integrációs keretéhez jussunk. Egyre jobban látszik az is, mennyire alkalmatlanok erre a feladatra az önmagukban természetesen indokolt és érvényes kritikai narratívák is. Vajon a sikeres válaszok az alábbi kérdésekre közelebb visznek-e az igényelt átfogóbb megértéshez? 'Hogyan fékezzük meg a BigTech-világot' (Barendregt 2021), 'hogyan bizonyítsuk ismételten a kapitalizmus ember-társadalom-és értékellenességét', vagy 'hogyan sodorja a szakadék peremére az ipari civilizáció és a fogyasztás-központúság az emberiséget’?

Úgy vélem, a társadalmi makroevolúciós nézőpont és a kontrollstruktúra-váltás fényében a kritikai narratívák is könnyen megtalálják a helyüket. Ez a fogalompáros értelmezhetővé és elemezhetővé tesz minden, intellektuális tárgylemezre kiszemelt kortárs jelenséget. A problématér fraktálossága pedig, mint láttuk, megfelelő lehetőséget kínál ahhoz, hogy a részproblémák vizsgálatát az „Egész” felől láthassuk és láttathassuk.

Vegyünk egy tipikus részkérdést, a munkamegosztás, a munkavégzés és a foglalkoztatás világát, amelynek statisztikai változása már az információs

\footnotetext{
${ }^{22}$ Abonyi és Miszlivetz (2016) könyvük harmadik fejezetében az Ipar 4.0 megoldások kialakításának társadalmi feltételeit tárják fel, a humán rendszermérnökség jelentőségének hangsúlyozásával. Belényesi (2018) amellett érvel, hogy az Ipar 4.0. a fejlődő országoknak több esélyt teremt, mint veszélyt: a 'smart'-technológia alkalmazása életszínvonal-emelkedést jelenthet, segíthet a szegénységből való kiemelkedésben. Jó érzékkel veszi észre a nemzeti szakpolitikák csökkenő szerepét is. Molnár (2018) viszont a fejlett országoknak a diszruptív technológiai változásokkal összefüggő zavarai és kockázatai között a középosztály megrendülését, az egyenlőtlenségek növekedését, a polarizálódást, az idősödéssel kapcsolatos gondok erősödését azonosítja - új társadalmi szerződésért kiáltva. Jellemzőnek tartom, hogy a majd 1500 japán vállalatot összefogó üzleti szövetség, a Keidanren pontosan ugyanígy látja: saját stratégiai állásfoglalásában (Keidanren 2018) egyenesen a szereplők közös alkotásának, ko-kreációnak láttatja a Társadalom 5.0-át, felismerve, hogy annak az üzleti filozófiának lassan vége, amely kizárólag a profitban tud gondolkodni. Ám ha az egész innovációs ökoszisztéma a társadalmi célok szolgálatába áll is, éppen ennek köszönhetóen nyílhatnak meg új üzleti lehetőségek (amire például az idősödés és a katasztrófatürés erősítése, Japán két legnagyobb társadalmi kihívása kínál kézenfekvő terepet).

${ }^{23}$ Folyóiratunk 2019-ben foglalkozott mindezzel, egy politikusbeszéd kapcsán, szerkesztői előszóként. Tegyük a humanizmust a digitális transzformáció középpontjává! Információs Társadalom 19 (1):123-129.
} 
társadalom érzékelésének is fontos indikátora volt. Az utókor által „mainstream” szerzővé avatott Fritz Machlup és Marc-Uli Porat nyomán így lett jól dokumentálhatóvá és mérhetővé az 1960-as évektől az információ- és tudásszakmák munkaerőpiaci előretörése, tovább zsugorítva az agrár- és ipari foglalkoztatás abszolút számait és relatív arányait.

És napjainkban? Grafikonok, interpretációk és előrejelzések között kapkodjuk a fejünket, hogy vajon az automatizáció és a mesterségesintelligencia-fejlődés új korszakai milyen hatást gyakorolnak az állásokra és a munkaerőpiacra. A szellemi agymunka algoritmizálhatósága és gépesíthetősége vajon a tudásszakmák csökkenésének nyit-e utat? A globális munkamegosztásnak (global division of labour) az agyelrablás (brain drain), az agyak visszanyerése (brain gain) és az agyak megosztása (bran sharing) mellett mik a friss tendenciái, fejleményei? Miképp kell értékelnünk, ha ügyintézési-tranzakciós vagy kutatási feladatok újabb körében tapasztalunk állam- vagy kontinenshatárokat átlépő kihelyezést?

Magyarországon azt látjuk például, hogy (az 1990-es évek elején elinduló trend még mindig tart, az információs és kommunikációs szektorban rendre nő a vállalkozások és a foglalkoztatottak száma (meg a keresetek), a hozzáadott érték és a termelési érték is. Az új vállalkozások 2/3-a ebben az ágazatban realizálódik (KSH 2021). Eközben (térségünkkel, Közép-Kelet-Európával együtt) a fejlett országokban tapasztalható recesszió ellenére továbbra is emelkedik a tudásintenzív munkahelyek száma és aránya az összfoglalkoztatottakhoz képest. Budapest városrégiója például Pozsony és Prága után harmadik e sorban, megelőzve Stockholmot, az Oberbayern régiót és mindenki mást (Sanandaji 2021). A munkaerőimport iránya ebben a szegmensben Nyugatról és Északról Kelet és Dél felé tart.

Csakhogy ettől még a tudásipar központja Párizs, London és a skandináv régió marad, amit jól bizonyít az ide és a térségünkbe áramló befektetések összege közti extrém különbség is. Mindez pusztán annyit jelez, hogy a centrumországok lassan „kinövik” saját információs társadalmuk foglalkoztatási szerkezetét, miközben az európai félperiféria éppen „belenő” abba. S természetesen mindezt nem valamiféle rendszeralakító intencionalitás szabályozza, hanem a tranzakciós költségek csökkentésének imperatívusza.

Ám vessünk egy pillantást arra, hogy mely területeken növekszik a foglalkoztatás az euroatlanti világban, és a belső munkaerőpiac korlátait honnan származó munkavállalókkal ellensúlyozzák?

Azt látjuk, hogy a humán gazdaság (szociális munka, idős- és gyermekgondozás, egészségügy, oktatás, lelki-egészségi- és tréningipar, kulturális ágazat, más szótárakban: érzelmi és kognitív munka) emelkedő mutatói állnak szemben a stagnáló tudás- és a csökkenő információs iparági számokkal. Ezek azok a munkakörök, ahol szívó hatás érvényesül, és ahová Kelet-Euró- 
pából és részben Ázsiából) a legtöbb munkavállaló érkezik. ${ }^{24}$ És ez az irány, ami nagyon pontosan jelzi, hogy milyen jövő felé tartanak a centrumországok, és mit „engedhetnek” már át a korábbi időszak kulcságazataiból a feltörekvő térségeknek.

Ám az egyéni sors- és lakóhelyválasztások mögött már nem a tranzakciós költség, hanem a legtágabb értelemben vett feladatváltási költség (task-switching cost) áll (Goldsby 2012). Az eredetileg az 'én állítsam elő vagy cseréljek' dilemmára kidolgozott modell érvényesnek tűnik a 'költözzek vagy maradjak', de akár a 'cseréljek-e szakmát a költözéshez vagy maradáshoz' típusú individuális és családi döntések kisvilágaira is. És ugyanígy privát választások azok a fogyasztói döntések is, amelyek a létfenntartáson túl arra vonatkoznak, hogy az egészségbe, kulturális élményszerzésbe vagy életminőség-javító technológiákba (humán technológiai termékekbe ${ }^{25}$ ) ruházzunk-e be? Az egymást részben feltételező és kiegészítő termelői és a fogyasztói döntések azonban együttesen egy olyan emergenciafolyamatot erősítenek, ami adott irányba alakítja a termelés és a fogyasztás szerkezetét: tárgyszinten egy újabb nagy átrendeződés felé, a humán tartalmak, rendszerszinten pedig a korábbi beszállítói értékláncokra rátelepülő globális koordináció és áramlások irányába. Egy olyan funkcionális rendszerszintugrás körvonalazódik ki, amely az élő rendszerek kezdetei óta jellemzi az evolúciót ${ }^{26}$ : a tranzakciós és feladatváltási költségek fokozatosan csökkentik a korábbi, immár alrendszerré váló szint autonómiáját a munkamegosztás átrendezésével, de ennek előnyei a magasabb rendszerszinten mutatkoznak meg.

\footnotetext{
${ }^{24}$ Természetesen nem csak ide: az új generációs importszakmák csak rátelepülnek egy előző hiányvilágra, ahol a munkavégzéstípusoknak a 'magasabb szintű' tudásmunka felé nivellálása és a csökkenő aktív népesség épp az 'alacsonyabb szintü' ipari-bedolgozó és a szolgáltatások világának kiszélesedését követő idegenforgalmi, vendéglátóipari és szervizipari szakmakörökben is átszippantott milliókat.

${ }^{25}$ A technológiatipológiák egyik legfájóbb hiánya, hogy a végfelhasználás szempontjából üzletre, gyártásra és szolgáltatás-biztosításra fejnehéz: sokkal ritkábban vizsgáljuk szisztematikusan, hogy a technológia hogyan járul hozzá a tudás termeléséhez, a jól-lét (well-being) erősítéséhez vagy a személyes fejlődéshez. Ez persze fordítva is igaz: a munkatipológiák is a foglalkoztatotti világ állástípusait tükrözik vissza, elfeledkezve arról, hogy a gyermeknevelés, az otthonfenntartás, a szülősegítés, az önkéntes tevékenység szintén értéktermelő munka. A leginkább a nők háztartási munkavégzésére például egyszerre igaz, hogy életminőség-javító technológiai és termékinnovációk szabadítják fel az életidőt más tevékenységekre, ám az időnyereségnél mégis sokkal jellemzőbb az időszegénység (Zorigt 2021). Mindennek különös zamatot ad, hogy Masuda „komputópiájában” az információs társadalmi állapot elérésének egyik legfontosabb indikátora az időérték központivá válása. Ettől láthatóan messze vagyunk még, de Norbert Wiener elhíresült szállóigéje - a kényszertevékenységek, futószalagok és gépek kiszolgálása helyett „emberi célra használni az embereket” (human use of human beings) - nagyon is aktuálissá vált (Wiener 1950).

${ }^{26}$ Az állatvilágban például a tranzakciós költségnek a létfenntartást támogató tevékenységek energiaigénye, feladatváltási költsége a csoportlétből származó előnyök miatt részlegesen feladott autonómia.
} 
Rögtön belátható az is, miért az „ellentézise” ennek a mozgásnak a militarizmus $^{27}$, a nagyhatalmi-titkosszolgálati logika, a dermesztően cselekvőképtelen világszervezeteket gúzsba kötő politikai partikularitás, és a mindezekkel öszszefonódó vas-acél-szén-olaj iparági komplexum minden utóvédharca. Ahová ebből a szögből rálátunk, az is megírásra vár még: az információs társadalom e 'Pitavaljában' régi idők nagy bűneseteinek mai megfelelői sorakoznának, rámutatva, miképpen kellene és lehetne meghaladni mindezt, új idők új közösségi-intézményi megoldásaival.

\section{Széljegyzetek egy panteonhoz. Megkésett búcsúzás, óvatos újraértékelés}

'Az információs társadalom klasszikusai' (ami a folyóiratunk mögött álló műhely Gondolat Kiadóval közösen gondozott elmélettörténeti könyvsorozatának címe is volt) nemcsak szerzőként kerültek elő az Információs Társadalom évfolyamaiban, hanem egy-egy jeles gondolkodó halálakor a szerkesztőség igyekezett röviden meg is emlékezni az életéről és a műveiről.

Különösnek mondható, hogy épp a diskurzus három, talán legjelentősebb alakjának esetében maradt el mindez. Amikor néhány szóval törlesztem az adósságot, rögtön arra is választ keresek, hogy az információs társadalom utáni beszédmódban maradt-e, lehet-e még jelentőségük.

A „nagy generációból” elsőként Tadao Umesao (1920-2010) távozott, akit a világ nyugati fele alig ismert, hiszen alapművei sokáig nem jelentek meg a világnyelveken, csak hazájában, Japánban. ${ }^{28}$ A folyóirat nyitó számban (Z. Karvalics 2001) az „információs társadalom” atyjaként mutattam be az akkor nyolcvan éves, még mindig rendkívül aktív tudóst, aki az azóta eltelt húsz évben históriai adalékká fakult az információs társadalom irodalmában. A szakcikkek és könyvek bevezető fejezetei előírás-szerűen „felmondják a leckét”, hogy Umesao 1963-as írása teremti meg az információs társadalom diskurzust Japánban. Mostanra azonban sokkal jobban látszik már, hogy a japánok fogalmi innovációja valójában a modernizáció, a tradíció és a Nyugathoz való viszony szakadatlan újrafogalmazásának kulcsmozzanata volt, mert „komputópiájuk” a huszadik század végére, modernizációjuk befejezésének idő-

\footnotetext{
27 Szép példa minderre az integráltsági szintjét éppen csökkentő Anglia erősödő fegyverkezési ambíciója. Boris Johnson 2021. március 16-i beszéde és az abban megfogalmazott terveket kidolgozó 114 oldalas jelentés (A globális Nagy-Britannia a versenykorszakban / Global Britain in a Competitive Age) nyomán a szigetország a hidegháború óta tartó folyamatos csökkentés után a következő években jelentős mértékben, 40\%-kal, 180-ról 260-ra növelni fogja a bevethető atomtölteteinek számát. https://www.wsj.com/articles/britain-to-boost-nuclear-weapons-stockpile-in-defense-policy-shift-11615919479

${ }^{28}$ 2001-ig egyetlen műve jelent meg angolul, egy japán kiadó gondozásában (Umesao 1986), de néhány év múlva civilizációelméleti főművének a róla szóló írásban is beharangozott angol kiadása részben pótolta ezt a hiányt (Umesao 2003).
} 
pontjára nemzeti identitás- és büszkeségképzővé válhatott (Rieu 2001/2013). Kétségkívül Umesaoé volt az inspiráció, de Yoneji Masuda lett a legfontosabb frontharcos (Duff 2020). Az utókor ma inkább etnográfusként tartja számon Umesaót, akinek épp civilizációelmélete áll újrafelfedezés előtt, nem kis részben a kínai „Új Selyemút” koncepciónak köszönhetően. (Az alábbi, gyakran közölt ábráját ma infografikai mesterműnek mondanánk, mert egyszerüsége ellenére nagyon sok rejtett összefüggést képes kibontani.)

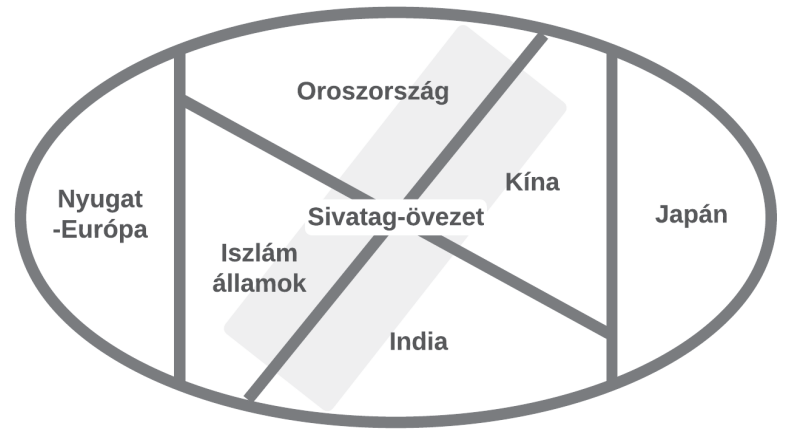

1.ábra: Eurázsia világmodellje, ahogy Umesao 1957-ben megrajzolta (Forrás: https://www.grips.ac.jp/teacher/oono/hp/lecture_J/lec01.htm)

Umesao után alig egy évvel hunyt el amerikai kollégája, Daniel Bell (19192011), akit viszont olyan „szociológusfejedelemként” búcsúztatott a világ, ${ }^{29}$ akinek a munkásságában a posztindusztrialitás fogalmi megragadása csak része volt a kortárs kapitalizmus társadalmáról adott látleleteknek. ${ }^{30} \mathrm{Az}$ ideológia végéről (Bell 1960) és a kapitalizmus kulturális ellentmondásairól írt munkái (Bell 1976) be is kerültek a huszadik század második felének 100 legfontosabb könyve közé, ${ }^{31}$ a posztindusztriális társadalommal foglalkozó, az analízistől az előrejelzés felé elmozduló nagy monográfiája (Bell 1973) viszont nem. Klaszszikussá az információs társadalom társas keretrendszeréről írott tanulmánya avatta (Bell 1980), nem véletlenül lett ennek fordítása az Információs Társadalom debütáló számának vezető írása.

\footnotetext{
${ }^{29}$ Bellről magyarul a 2014-ben felszámolt Galamus oldalán jelent meg (ma már nem elérhető) alapos értékelő nekrológ. A temérdek angol nyelvű visszaemlékezés közül talán a legérdekesebb a születése 100. évfordulóján megjelent, sok személyes elemet tartalmazó írás, Bell társadalomtudóssá lett fiától, David A. Belltől. https://www.dissentmagazine.org/online_articles/ daniel-bell-at-100

${ }^{30}$ Természetesen azok, akik Bell kapitalizmuskritikáját kevesellték, azok inkább a kapitalizmus apológiájaként olvasták és láttatták a művét - mint Mészáros István (1989), aki groteszk Weber-epigonnak tartotta (Singer 1990). Egy friss elemzés (Ramirez Plascencia és Solis Gadea 2017) Bellnek azt az alaptézisét tartja elavultnak, hogy a kultúra radikális változása miatt inkompatibilissá vált a kapitalista gazdaság újratermelésével (miközben Weber félreolvasását vetik a szemére).

${ }^{31}$ A Times Literary Supplement listájában rajta kívül csak öten szerepeltek két munkával is.
} 
Bell információs társadalomhoz vezető gondolkodói útjának (amelyről szép és alapos elemzést közölt Duff 1998) záró epizódja a posztindusztriális társadalomról írott könyvének 1999-es újrakiadásához írt zsebkönyvnyi előszava. Ebben megvallja, hogy korábban azért nem információs társadalomként beszélt a formálódó új minőségről, mert meggyőződése volt, hogy nem lehetséges holisztikusan közeledni hozzá: csakis három, egymástól különböző, elkülönülő (diszjunkt) színtérként tud gondolni a gazdasági-technológiai, a politikai és a kulturális világra (és ez a különbség valóban hangsúlyosan megmutatkozik, ha ráismerünk például globalizálódásuk eltérő mértékére). És most sem teszi: annak szentel új részeket, hogy mi következik a technológiai forradalom legfrissebb (a 90-es évek Internetje által fémjelzett) szakaszából, és miért beszélhetünk információs korszakról (amelyben az „intellektuális technológia” nemcsak „hidat ver” technológia és társadalom közé, hanem ahogy egykor az elektronikus technológia „nőtt rá” a mechanikaira”, úgy nő most rá az intellektuális technológia az elektronikaira). A tudás növekedését azonban - a technológiával ellentétben - nem tartja robbanásszerűnek.

Bell e késői reflexiója már nemigen ad hozzá a diskurzushoz, Castells nagy monográfiája (amellyel, érdemei elismerése mellett, Bell kicsit kötözködik) a technológia, a társadalom, a gazdaság és a kultúra minden szegletébe sokkal alaposabban világít be.

Ám eközben, a ma már kissé száraznak és törékenynek tűnő teoretikus karácsonyfájára, mintegy mellékesen, számtalan figyelemre méltó gondolatdíszt aggat. Tudatosítja és üdvözli, hogy milyen mértékben nőtt meg az ezredfordulóra a nők szerepe és bevontsága. Vészharangot kongat, amikor a tudástermelés legfontosabb alrendszerének tekintett tudományra ránövő politikáról vagy a bürokratizáció fenyegette tudományról beszél. Eljut Masuda gondolatához, hogy az időmenedzsment válik a legfontosabb kérdéssé, de emellé még a méret menedzsmentjét (management of scale) is hozzáilleszti, aláhúzva a bürokratikus döntéseit központosító nemzetállam növekvő alkalmatlanságát az egyre átfogóbb koordinációt igénylő kérdésekben. És itt az információtechnológia sem segít, hiszen érzéketlen az információ és a releváns információ közti különbségre, s miközben az információt lehet mérni, az információ érvényességében és használatában megtestesülő értékhozzáadást nem. (Ezt Bell a döntés, megítélés, véleményformálás modalitásait egyaránt tartalmazó 'judgement' szóval fejezi ki.)

Ha a harmadik „testőr”, az etnográfus Umesaoval és a szociológus Bell-lel szemben jövőkutatóként számon tartott Alvin Toffler (1928-2016) ${ }^{32}$ tartja a tőle megszokott tízéves megjelenési ciklusidőt, a korábbi trilógiáját tetralógiává nö-

\footnotetext{
$\overline{32}$ Nem véletlen, hogy halálára a jövőkutató céh figyelt fel: nevükben Kömlődi Ferenc (https:// digit.mandiner.hu/cikk/20160706_az_informacios_kor_jovosokkjai) búcsúzott úgy Tofflertől, hogy néhány saját gondolattal túllépett a gyászhírt pusztán magyarító tudósításokon (https:/l infostart.hu/kultura/2016/06/30/meghalt-alvin-toffler-a-harmadik-hullam-szerzoje vagy https://24.hu/tudomany/2016/07/02/elhunyt-a-jovokutato-aki-megjosolta-milyenek-leszunk/).
} 
vesztve lezáró kötetéről már írhattunk volna a debütáló folyóiratszámban. Erre azonban még jó pár évet várni kellett (Toffler 2006). Bátran mondhatjuk, hogy a Jövősokkot (Toffler 1970), A harmadik hullámot (1980) és a Hatalomváltást (1990) követő Forradalmi bőség kerekké és lezárttá tett egy különös életmüvet. ${ }^{33}$ Nagyon leegyszerüsítve és sajátságosan értelmezve Toffler évtizedeken át formálódó gondolatmenetét: a jövősokk-gondolat a világban végbemenő változásegyüttes individuális megélésének nehézségére, árnyoldalaira figyelmeztetett. A harmadik hullám metaforája viszont kontextusba helyezte mindezt, nagyon meggyőzően érvelve amellett, hogy a változás civilizációs szemmel mégis szükségszerü és feltartóztathatatlan. A hatalomváltás anatómiája ezer apró kisablakot nyitott arra a konfliktustérre, amelyben az átalakulás zajlik, a régit és az újat képviselő erők könyörtelen küzdelmeként. A forradalmi bőség a civilizációs átalakulás kézzelfoghatóvá válásának könyve: egyszerre láttatja a megnyíló csatornákat és a feltáruló veszélyeket, konstatálva, hogy minden „összeér”: az individuum egyidejűleg termelővé és fogyasztóvá válása (a prosumer-lét), a kapitalizmus haláltánca, az alternatív értékcsereformák, az elalkalmatlanodó nemzetállamok és modernitásintézmények, valamint az elavuló tudások egyaránt a globális koordináció új minősége felé mutatnak utat (amelynek része a közvetlen kozmikus környezet meghódítása is). A jövő megérkezett, a sokkot immár inkább a megnyíló perspektívák kínálják, a fó veszélyt pedig a tanulás és az újratanulás képességének hiánya hordozza. (Kis rosszindulattal azonban azt is mondhatnánk, hogy abban a pillanatban, ahogyan a társadalmiból a természetire ugrunk, megtaláljuk a valódi sokkképző elemet, a klímaegyensúly szélsőséges időjárással, fenntarthatósági veszélyekkel és pandémiákkal beköszönő felbomlása formájában - ami 15 évvel ezelőtt még nem mutatkozott meg ennyire kifejlett narratívaként, emiatt kerülhette el Toffler figyelmét is.)

Toffler egyedi szerkesztésmódja miatt művei összefoglalhatatlanok, hiszen még ha nagyvonalúan és elegánsan is, de kaleidoszkópszerűen építkezik. Olyan, mintha egy légy összetett szemén keresztül látnánk a világot. Milliónyi esemény, fejlemény, történet adja a szöveg testét, apró, könnyen emészthető, rövid alfejezetecskék sokaságával, jellemzően technológia és társadalom metszéspontjain. Csak a cseppeket mutatja nekünk, de tudjuk, hogy jótékony

\footnotetext{
33 A tetralógia nyitó darabjának nincs teljes magyar fordítása és kiadása. A Jövősokk fontosságára jól ráéreztek a Korunk szerkesztői, amikor 1971/12-es számukban kivonatos összefoglalást adtak (Farkas László tollából (1877-1887.o.) A Nagyvilág is lefordított és megjelentett egy részletet 1972/7-es számában, és nyomtatott-sokszorosított egyetemi jegyzetekbe is bekerültek a könyvből részletek. A Harmadik hullám a Typotex kiadónál, Rohonyi András fordításában (2001), a Hatalomváltás az Európa Kiadónál M. Nagy Miklós fordításában (1993) jelent meg. Talán nem túlzott elvárás az akadémiai és kiadói világtól azt remélni, hogy előbb-utóbb a tetralógia minden kötetének legyen teljes magyar fordítása és kiadása. Meg kell jegyeznünk végül, hogy létezik olyan megközelítés, ami szerint a Hatalomváltás-kötetnek van egy „ikre”, a túlélés, a konfliktusok és a háborúk kérdését tárgyaló War and Anti-war címủ kötet (Toffler 1993), a Harmadik hullámnak pedig egy karcsúbb „utóirata”, kiegészítése, amelyben a Toffler-házaspár annak politikai dimenziót elemzi (Toffler 1995).
} 
csalás áldozatai vagyunk. Nem mindegy ugyanis, hogy a milliónyi lehetséges cseppből melyikben látjuk a változások legjobb hírnökeit tükröződni. Toffler erősen szelektál tehát, majd a darabkákat rafináltan rendezi egymás mellé: kompozíciójukból mégiscsak kirajzolódik a tenger képe, de ezt nem rágja a szánkba, hanem hagyja, hogy magunk építsük fel azt (igaz, az általa kínált és szenvedélyesen sugallt rendezőelvek és jelentések mentén ${ }^{34}$ ).

Az információs társadalom diskurzus „nagy generációja” után látszólag már csak az elemzők és historiográfusok (mint Frank Webster vagy Alistair S. Duff) maradtak a porondon. Méltatlanul elfeledkeznénk azonban a 85. évében járó Andrew Targowskiról. A három testőrhöz képest D’Artagnannak tűnik 1937-es születési évével, de Magyarországon alig ismert életmüve ismeretében bátran állíthatjuk, hogy a felsorolásokban lassan illene a többiek neve mögé biggyeszteni az övét is.

A „lengyel Masudáról”, Targowskiról annak kapcsán hallhattunk eddig, hogy a hetvenes években az INFOSTRADA koncepcióval (1972-1975) ő szerette volna Lengyelországot egy decentralizált és számítógépesített társadalomirányítási modell felé elmozdítani, japán kortársaival egyidőben. A korabeli „Szovjet tömb” országait ismerve nem meglepetés, hogy emigrálnia kellett, és azóta az Egyesült Államokban (Kalamazoo, Michigan) él, tanít, tervez és ír könyveket. Nem is keveset. Lassan félszázra rúgó termésének induló darabjai kifejezetten az információs társadalom gondolata köré szerveződnek, része volt az Al Gore-féle információs szupersztráda-program kialakításában (Targowski 1996), az ezredforduló után megalkotta az információs társadalom 14 elemű taxonómiáját (Targowski 2005), ezt alkalmazta állami, regionális és települési (város, falu) szintre is. 2008-ban (majd 30 év után) módjában állt tervet készíteni szülőhazája információstársadalom-fejlesztésére (igaz, nem kormánya, hanem a feladattal megbízott nemzetközi tanácsadó cég felkérésére). S miközben mindazt, amit az információs társadalomról gondol, „varsói Tofflerként” egy monográfiába rendszerezte (Targowski 2009). Ebben információtechnológia és társadalomfejlesztés közös metszetét keresve azt csakis egy rendszeres kifejtésen alapuló civilizációs kontextusban tudja megragadni - „lengyel-amerikai Umesaoként” megnyitva ezzel az utat, önálló civilizációelméleti monográfiák sorának.

Önálló könyvet szentelt a civilizáció globális (Targowski 2014) és virtuális (Targowski 2015a) természetének, korlátainak (Targowski 2015b), valamint az információhoz jutás és a civilizáció közti kapcsolatnak (Targowski 2016). (Társ)szerkesztett $a$ spiritualitás és a fenntarthatóság civilizációs összefüggéseivel foglalkozó kötetet (Targowski és Celinski 2013), majd egy-egy civilizációs „kultúrkör” (az afrikai, nyugati, kínai és japán) önálló portréösszegzéseit

\footnotetext{
${ }^{34}$ Ebből, nem véletlenül, a Forradalmi bőségben találunk a legtöbbet. Itt Toffler már nem elégszik meg a változások konstatálásával, szerkezeti sajátosságok köré rendezi a tárgyát (amelyeket ő „mély alapoknak” (deep fundamentals) hív: az idő, a tér és a tudás kategóriában igyekszik megragadni a lényegi mozzanatokat.
} 
is elkészítette. ${ }^{35} \mathrm{~S}$ eközben az intellektuális technológia „lengyel Belljeként” mindenki másnál alaposabban nézett az információtechnológia körmére: a vállalati információs rendszerek sokkönyves kutatójaként és tanáraként a „klasszikus” információtechnológiától (Targowski 2016b) a „kognitív informatikáig” (Targowski 2010) az adatoktól a bölcsességig igyekezett a horizontot tágítani (Targowski 2013).

A Targowski-életmű (amely még továbbra is folyamatosan gyarapszik) mindenesetre jó orvosságnak tűnik, ha borongani kezdenénk, akár az információstársadalom-diskurzus hanyatlása, akár világunk, civilizációnk állapota, akár az interdiszciplináris kutatások szélárnyéka miatt. Benne biztos kezű kalauzra lelünk, amikor hármas utakhoz érkezünk. Ideje felfedezni, fordítani, kiadni, összefoglalni a munkásságát - nem megvárva, hogy múlt időben beszélhessünk róla (is).

És illesse tisztelet az összes régi és új muskétást ${ }^{36}$, akik minden nehézség és megpróbáltatás ellenére húsz éve tartanak ki, hogy Magyarországon egy negyedéves társadalomelméleti szakfolyóirat megjelenhessen, megújulhasson, fórumot biztosítva az információstársadalom-gondolkodásba bekapcsolódó régi és új szerzőknek. Lebegjen valamennyiük szeme előtt a rettenthetetlenül termékeny Alexandre Dumas, aki még a Húsz év múlva című könyvéhez is újabb darabokat illesztett (az öt kötetben megjelent Bragelonne vicomte, vagy tíz évvel később címmel magyarul is több kiadásban megjelent regényfolyamot). Mi is megfelezhetjük az átugrott időt: térjünk vissza tíz év múlva az információstársadalom-kutatások aktuális állására.

\footnotetext{
${ }^{35}$ Ezeket nem soroljuk fel egyesével, áttekintésüket lásd a kiadó Nova Publishers oldalán. https://novapublishers.com/writer/andrew-targowski/

${ }^{36}$ Ejtsünk egy szót az emberek mellett a szakosított kutatóintézetekről is. Meg kellett érnünk, hogy az információs társadalom kutatásának kiváló nemzetközi (salzburgi és tamperei) mühelyei létrejöttek, majd megszűntek, ebben a pillanatban Barcelonában van a legnagyobb létszámú és hatású információstársadalom-kutató mühely. Itthon alig élte túl saját 15 éves évfordulóját a BME-UNESCO Információs Társadalom és Trendkutató Központja, az ITTK (19982014), a jubiláns folyóiratot is elindító szakmai mủhely. 2015-től három éven át új köntösben, az Óbudai Egyetem Digitális Kultúra és Humán Technológia Kutatóközpontjaként próbálta tovább vinni az ITTK-szellemet, de 2018-ban megszűnt, akárcsak az egykor tucatnál is több egyetemi (köztük határon túli magyar) hídfőállással rendelkező ITOK-hálózat (Információs Társadalom Oktató és Kutató Csoportok). Ennek egyetlen túlélője, mai napig aktív D’Artagnanja azért létezik, a Dr. Élő Gábor által vezetett győri csoport, a Széchenyi István Egyetemen. Létrejött, úttörő volt, majd megszűnt az információs társadalom jogi kérdéseivel foglalkozó pécsi egyetemi oktató- és kutatóközösség (Informatikai és Kommunikációs Jogi Kutatóintézet). Ma a témakör dedikált szakmai kutatóhelyeként egy meghatározó szereplőt találunk a diszciplináris térképen: a Nemzeti Közszolgálati Egyetem Információs Társadalom Kutatóintézetét.
} 


\section{Irodalom}

Abonyi János és Miszlivetz Ferenc. Hálózatok metszéspontjain: A negyedik ipari forradalom társadalmi kihívása. Szombathely: Savaria University Press, 2016.

Tech Otherwise.pubpub. Barendregt, Wolmet, Christoph Becker, EunJeong Cheon, Andrew Clement, Pedro Reynolds-Cuéllar, Douglas Schuler, and Lucy Suchman. „Defund Big Tech, Refund Community: Anti-Trust is Not Enough, Another Tech is Possible.” Utolsó hozzáférés: 2021. május 1. https://doi.org/10.21428/93b2c832.e0100a3f

Beck, Ulrich. Risikogesellschaft: Auf dem Weg in eine andere Moderne. Frankfurt: Suhrkapmf Verlag, 1986. Továbbfejlesztett változatának magyar kiadása: Beck, Ulrich. A kockázattársadalom - Út egy másik modernitásba (Budapest: Andorka Rudolf Társadalomtudományi Társaság/Századvég Kiadó, 2003.)

PAGEO Geopolitika Kutatóintézet. Belényesi Pál. „A negyedik ipari forradalom és a fejlődő országok feladatai, valamint lehetőségei.” Utolsó hozzáférés: 2021. május 1. http://www.geopolitika.hu/hu/2018/12/17/a-negyedik-ipari-forradalom-es-a-fejlodo-orszagokfeladatai-valamint-lehetosegei/

Bell, Daniel. The End of Ideology: On the Exhaustion of Political Ideas in the Fifties. New York: Free Press, 1960.

Bell, Daniel. The Cultural Contradictions of Capitalism. New York: Basic Books, 1976/1996.

Bell, Daniel. The Coming of Post-Industrial Society: A Venture in Social Forecasting. London: Heinemann/Basic Books, 1973/1999.

Bell, Daniel. „The Social Framework of the Information Society.” In Dertouzos, Michael L. és Joel Moses (Szer.). The Computer Age: A Twenty-Year View, 163-212. Cambridge, Massachusetts: The MIT Press,1980.

Chayko, Mary. Superconnected: The Internet, Digital Media, and Techno-Social Life Thousand Oaks, CA: SAGE Publications Inc, 2019.

Craglia, Massimo (Ed.). Digitranscope. The governance of digitally-transformed society.

Luxembourg: Publications Office of the European Union, 2021. https://op.europa.eu/hu/ publication-detail/-/publication/a4a0928e-8152-11eb-9ac9-01aa75ed71a1

Duff, Alistair S. „Daniel Bell's theory of the information society.” Journal of Information Science 24, no. 6 (1998): 373-393.

Duff, Alistair S. „Computopia Revisited: Yoneji Masuda’s realistic utopianism.” Keio Communication Review 42, no. 3 (2020): 53-74.

Füzesi Péter és Holtzer Márton. „Amerikai história. James R. Beniger: Az irányítás forradalma. Az információs társadalom technológiai és gazdasági forrásai.” Információs Társadalom VI, 1. szám (2006): 114-123. DOI: https://doi.org/10.22503/inftars.VI.2006.1.12

G. Márkus György. „A modernitás rendszerváltása. Ulrich Beck: A kockázattársadalom. Út egy másik modernitásba.” Politikatudományi Szemle XII, 4. szám (2003): 249-259.

Goldsby, Heather J., Anna Dornhaus, Benjamin Kerr, és Charles Ofria. „Task-switching costs promote the evolution of division of labor and shifts in individuality” PNAS 109, no. 34 (2012): 13686-13691. https://doi.org/10.1073/pnas.1202233109

Holroyd, Carin. Technological innovation and building a 'super smart' society: Japan's vision of society 5.0.” Journal of Asian Public Policy Apr.29. (2020): 1-15.

DOI: $10.1080 / 17516234.2020 .1749340$ 
Katona Eszter, Knap Árpád, Máté Fanni, Csótó Mihály. „Az Információs Társadalomban megjelenő tanulmányok topikelemzése” Információs Társadalom XXI, 1. szám (2021): 10-47. DOI: https:// doi.org/10.22503/inftars.XXI.2021.1.1

Keidanren. „Society 5.0: C-o-creating the future (Expert) Keidanren.” Utolsó hozzáférés: 2021. május 1. https://www.keidanren.or.jp/en/policy/2018/095 outline.pdf

KSH. „Az információ, kommunikáció nemzetgazdasági ág helye Magyarország nemzetgazdaságában.” Utolsó hozzáférés: 2021. május 1. www.ksh.hu/docs/hun/xftp/idoszaki/ ikt/2021/03/digitalis gazdasag tarsadalom 3.pdf

Masuda, Yoneji. The Information Society as Post-Industrial Society. Tokyo: IIS, 1980.

Magyarul: Masuda, Yoneji. Az információs társadalom mint posztindusztriális társadalom. Budapest: BME OMIKK, 1988.

Mészaros István. The Power of Ideology. New York; London; Sydney: Harvester Wheatsheaf, 1989. Mészáros István. „Lényegi egyenlőség és lényegi demokrácia.” Eszmélet 27., 107. szám

(2015 ősz): 5-11.

Molnár Szilárd. „A negyedik ipari forradalom nem várt hatásai” Új Magyar Közigazgatás 11, 3. szám (2018): 43-51.

Monostori László. „Cyber-physical production systems: roots from manufacturing science and technology.” At - Automatisierungstechnik : Methoden und Anwendungen der Steuerungs-, Regelungs- und Informationstechnik 63, no. 10 (2015):766-776.

Nagy Gábor Dániel és Z. Karvalics László. „Prokrusztész nélküli világ? Blokklánc és társadalmi makroevolúció.” Információs Társadalom XVII, 3. szám (2017):7-38. DOI: https://doi. org/10.22503/inftars.XVII.2017.3.1

Ramirez Plascencia, Jorge és Hector Raul Solis Gadea. „To reread to Daniel Bell. Forty years after the publication of The Cultural Contradictions of Capitalism.” Espiral: Estudios sobre Estado y Sociedad (Guadalajara) 24, 68. szám (2017): 9-35.

doi: http://dx.doi.org/10.32870/

Forrás: http://www.espiral.cucsh.udg.mx/index.php/EEES/article/view/5741/5641

Rieu, Alain Marc. Savoir et pouvoir dans la modernisation du Japon. Paris: Presses Universitaires de France, 2001. (Japán fordítása: Tokyo: Suisei-sha, 2013.)

Sanandaji, Nima. The Geography of Europe's Brain Business Jobs: 2021 Index. (s.l.): European Centre for Policy Reform and Entrepreneurship in collaboration with Nordic Capital, 2021.

Singer Daniel. „Mészáros István: Az ideológia hatalma.” Eszmélet 8. szám (1990 Tél) http://www.eszmelet.hu/daniel singer-meszaros-istvan-az-ideologia-hatalma/

Szalavetz Andrea. „Az ipar 4.0 technológiák gazdasági hatásai: Egy induló kutatás kérdései.” Külgazdaság 60, 7-8. szám (2016): 27-50.

Targowski, Andrew S.. Global Information Infrastructure: The Birth, Vision, and Architecture (Series in Global Information Technology Management). Harrisburg, Pennsylvania: Idea Group, 1996.

Targowski, Andrew. „The Taxonomy of Information Societies.” In: Lan, Yi-chen (Ed.) Global Information Society: Operating Information Systems in a Dynamic Global Business Environment. Hershey, PA: Idea Group Publishing, 2005.

Targowski, Andrew. Information Technology and Societal Development. Hershey, PA, London: Information Science Reference, 2009.

Targowski, Andrew (Ed.). (2010): Cognitive Informatics and Wisdom Development: Interdisciplinary Approaches. Pennsylvania: IGI Global, 2010. 
Targowski, Andrew. Harnessing the Power of Wisdom from Data to Wisdom. Hauppauge, New York: Nova Science Publishers, 2013.

Targowski, Andrew. Global Civilization in the 21st Century. Hauppauge, New York: Nova Science Publishers, 2014.

Targowski, Andrew. Virtual Civilization in the 21st Century. Hauppauge, New York: Nova Science Publishers, 2015a.

Targowski, Andrew. The Limits of Civilization. Hauppauge, New York: Nova Science Publishers, 2015b.

Targowski, Andrew. Informing and Civilization. Santa Rosa, California: Informing Science Press, 2016a.

Targowski, Andrew. The History, Present State, and Future of Information Technology. Santa Rosa, California: Informing Science Press, 2016b.

Targowski, Andrew és Marek J. Celinski. Spirituality and Civilization Sustainability in the 21st Century. Hauppauge, New York: Nova Science Publishers, 2013.

Toffler, Alvin. Future Shock. New York: Bantam Books, 1970.

Toffler, Alvin. The Third Wave. New York: Bantam Books, 1980.

Toffler, Alvin. Powershift: Knowledge, Wealth and Violence at the Edge of the 21st Century. New York: Bantam Books, 1990.

Toffler, Alvin és Heidi Toffler. War and Anti-War: Survival at the Dawn of the 21st Century. Boston, Massachusetts: Little, Brown and Company, 1993.

Toffler, Alvin és Heidi Toffler. Creating a New Civilization: The Politics of the Third Wave. Nashville, Tennessee: Turner Publishing Company, 1995.

Toffler, Alvin és Heidi Toffler. Revolutionary Wealth. New York City, New York: Alfred A. Knopf, 2006.

Umesao, Tadao. Seventy-Seven Keys to the Civilization of Japan. (s.l.): Heian Intl Pub. Co., 1986.

Umesao, Tadao. An Ecological View of History: Japanese Civilization in the World Context. Tokyo: Trans Pacific Press, 2003.

Wiener, Norbert. The Human Use of Human Beings: Cybernetics and Society. Boston, Massachusetts: Houghton Mifflin Harcour, London: Eyre \& Spottiswoode, 1950.

Z. Karvalics László. „Az információs társadalom gondolat európai szálláscsinálója: In memoriam Jean-Jacques Servan-Schreiber (1924-2006).” Információs Társadalom VII, 1. szám (2007):124-136. DOI: https://doi.org/10.22503/inftars.VII.2007.1.13

Z. Karvalics László. „A tudás termelése és elosztása az Egyesült Államokban. Fritz Machlup újraértékelése az információs társadalom elmélettörténetében” Információs Társadalom IX, 2. szám (2009a): 20-34. DOI: https://doi.org/10.22503/inftars.IX.2009.2.2

Z. Karvalics László. „A fehérgalléros forradalom krónikája: Jean Gottmann, az információs társadalom elméletének elfeledett úttörője.” Információs Társadalom IX, 3. szám (2009b): 53-66. DOI: https://doi.org/10.22503/inftars.IX.2009.3.3

Z. Karvalics László. A hierokratikus kontrollstruktúra születése. Világtörténet 41, 1. szám (2019):5-21.

Zorigt, Burtejin. „Több milliárd nő él időszegénységben a Földön” Utolsó hozzáférés: Qubit. 2021. május 1. https://qubit.hu/2021/04/06/tobb-milliard-no-el-idoszegenysegben-a-foldon? ga $=2.167802721 .1153203017 .1617621793-634123505.1550001632$ 